\title{
IMPROVING ENGLISH SPEAKING ABILITY USING THE SNOWBALL THROWING GAMES TECHNIQUE
}

\author{
Wibbie Putra Anugrah ${ }^{1}$, Dedi Wilana ${ }^{2}$, Evie Kareviati ${ }^{3}$ \\ ${ }^{1}$ IKIP Siliwangi \\ ${ }^{2}$ IKIP Siliwangi \\ ${ }^{3}$ IKIP Siliwangi \\ ${ }^{1}$ wibbiputra.wb@gmail.com, ${ }^{2}$ willianasaputra@gmail.com, ${ }^{3}$ akhmadjaelani91@yahoo.co.id
}

\begin{abstract}
In this study, the researcher used method Classroom Action Research (CAR) to improve the quality of the learning and teaching processes as well as to detect and solving the problems that found in the teaching and learning process. The subjects of this research were the 34 students in SMK Budi Bhakti Utama Padalarang. The researcher used collaborative action research with some English teachers in the school. In this study, the researcher using the instruments interview and questionnaire test to collecting the data. The test that given to students is pre test and also post test in the and of the class or after the students has a treatment. In this result of the study showed the mean score of pretest is 62.02 to 64.00 and post test's score reached up to 79.00. It is important to describe that there is a significant improvement of the test. Therefore, the criteria of success had been determined. It is crucial to remember that communicative games have contributed and positive impact on teaching and learning process. The communicative games like snowball throwing game expected to enhance students' motivation and enthusiasm in learning English. Clearly, It gives positive improvement on students' confidence and their fluency in speaking skill. In short, communivative games can be describing that the strategy of teachinglearning creates good, enjoyable circumstances and reduces the stress level and boredom in learning process.
\end{abstract}

Keywords: Snowball Throwing, Speaking,CAR

\section{INTRODUCTION}

Teaching and Learning English in Indonesia has been compulsory in elementary, junior, high school, until the higher level intuitions in Indonesia. The purpose of teaching English to students' is to improve knowledge of the students to apply the language in the daily school communication or in their social environment. By knowing English, the students are expected to be able to take part in social live and able to communicate even gain knowledge which is mostly using medium of English. In vocational high school, the learning of English should emphasize the students to mastering proficiency in four skills, i.e., speaking, reading, listening, and writing. In the same line with the final goals of English teaching, in Indonesia Curriculum of English (Kemendikbud, 2013) state that language competences which the vocational school students' must be mastering are directed particularly at the informational level of the other three levels, which are funtional, performatic, and epistemic.

According to Brown (2004: 140) in Parmawati (2018) "speaking is a productive skill that can be directly and empirically observed, those observations are invariably colored by the accuracy and effectiveness of the test-takers listening skill, which necessarily compromises the reliability and validity of an oral production test". Dewi (2016) in Parmawati and Inayag (2019) states that there are several factors that make it possible to make student speaking skills 
unsuccessful as follows: a) English is not used outside the classroom or in the community as a foreign language, b) Lack of exposure to English in the community and environment, c) learning English on campus lacks emphasis on speaking skills, but focuses more on the structure and enrichment of vocabulary, d) Shame and fear of making mistakes when speaking exercises, e) English is not a primary requirement, unless there is an opportunity to go to an Englishspeaking country to continue education or tourist visit. But in reallity it is hard for teachers to improve their students to learn English because to inviting the students for learning English is not enough just giving motivation, but it has another reasons and problem like, they are: the shyness of students in performing their ability, there many students in a class so it can be difficult for teacher to foccus in teaching English, and practically the students are not interest to learning english. Since language learning is a hard task. So, finally teachers have a big challenge to find some way and techniques to make the students can be motivated and active in learning English.

One techniques that can be used is by using games, like Snowball Throwing Games. Darusmin, Delfi, and Masyhur (2012,cited in Apsari, 2018) described snowball throwing method as one modification of an interesting game that is mutually throwing snowballs which contains questions to fellow friends which focuses on the ability to formulate question.

By using games teachers can make another atmosphere or better situation in a class that will enhance the students' desire to learn the language. enhance students motivation by using games in learning process will make they are learning better because they have some feeling that they has making improvement and games can make students had fun feeling, so it can omit their fear of learning English. (Jack Richard, 2006)

It is supported by Tengku Mohamad Maasum, Mustaffa, \& Stapa (2016) who believes that games are highly motivating in foreign language teaching because they are amusing and interesting they can be used to give practices in all language skills and can be used to practice all types of communication. And the other one is (Wright, 2005) mentions that games provide a context for meaningful communication, which takes place as the students seek to understand how to play the game and as they communicate about the game. nowday there is many games for teacher give to their students, teacher just only must maching their matherial and make it a game.

By using games in teaching-learning process are giving some foccus of communicative language practice, but in another way by using english language as living or daily communication to convey opinion and information. By using games, students will immersed in using the target of a curricullum or all four skills, which help them to better using a new vocabularies. From information that reseacher known, this problem are expand in SMK BBU Padalarang too. And they has implemented games in their teaching. Therefore the researcher make the study of "The Use of Games in Teaching English" at SMK BBU Padalarang. for more specific this study is aimed to: (1) giving information about games are used in Teaching English, (2) giving information about the problems faced by teachers in using games in teaching-learning process in a classroom, (3) sharing the information from students' opinion toward the use of games in learning process in classroom. (Puspita Ensa, 2018)

\section{METHOD}

This study belongs to descriptive research and it is classified into a case study. Subject of this research were some English teachers which were chosen based on head master's recommendation and 34 students in Budi Bakti Utama Vocational School Grade XII Technique 
of Motocycle Engine.

In this research, there are supporting instruments were used to help the researcher to analyze and collecting the data. The supporting instruments were interview guide, observation sheet, and some questionnaire for students. the researcher using observation sheet to observe the situation in the teaching-learning process in a classroom which were done eight times from September 4th to October 9th 2018. And The observation sheet consisted of five columns.

The column to be input consisted of definition of the game, students' activities, teacher activities in a class, notes, and date. Researcher using an interview guide to collect information about the use of snowball throwing game as one of strategies in teaching English at SMK BBU Padalarang of Grade XI.

In the end of the research, the reseacher giving ten questions as interview guide and it is conducted in Bahasa Indonesia for minimize the misunderstanding or misinterpretation. The students get ten questionnaires which were used to getting information from students' impression of using snowball throwing game in learning English. The questionnaires were distributed to students' of Class XI Technique of Motocycle Engine.

The data gained from data collection were analyzed through three stages is pretest, post test and interview to teacher english and some students. In the end of the observation, researcher gave meaning and interpretation to the data. In this context, the researcher gave meaning based on review of some literature are relate with this research.

The result of this research was presented and concluded in the form of specific and brief description.

\section{RESULTS AND DISCUSSION}

\section{Results}

The research carried to analyze in accordance with the research problems. In line with the research problems this research and discussion present some points based on data analysis, they are: (1) snowball throwing game used in and the implementation, (2) the problems of using game in teaching and learning English, (3) improvement that students' got in post test, and (4) the students and some teacher english opinion about using games in teaching learning English process.

On the book learning English cooperative by (Agus, 2009) describs the technique of snowball throwing games is some of active learning method for the direct attention of learners to the material presented. Step-by-step method Snowball Throwing game is:

1) Tearcher give some pre test

2) Teacher deliver the material that will be learnt using this technique.

3) Teacher deliver the materials as a treatment and students will be learnt using this technique (Stapa, 2008) Snowball Throwing Games.

4) Teacher make groups and call the chairman of a group for give an explanation about the material being taught to their students / members .

5) The group heads back to each group and explain any material submitted from teacher to his friends.

6) Each student is given a sheet of paper, to write down one question concerning any matter which has been described by the group leader.

7) The teacher giving a paper containing these questions was made into a ball and tossed one student to another student about 15 minutes. 
8) Then each student have one ball or one question and give their friend the opportunity to answer questions that are written in ball-shaped paper in turn

9) Post test.

10) Evaluation and giving students' opinion .

11) Closing.

Table 1. Meetings in cycle I

\begin{tabular}{|c|c|c|}
\hline & Acting & Observing \\
\hline Meeting & Topic & Activity \\
\hline 1 & $\begin{array}{l}\text { Pre-test: } \\
\text { Descriptive text. }\end{array}$ & $\begin{array}{l}\text { In this first meeting,the researcher gave } \\
\text { them } 17 \text { question to describe. }\end{array}$ \\
\hline 2 & $\begin{array}{l}\text { Treatment } 1: \text { Descriptive } \\
\text { text }\end{array}$ & $\begin{array}{l}\text { They describe about the descriptive text } \\
\text { that they have from the snowball. The } \\
\text { researchers give them snowball to discuss } \\
\text { and students gave } 1 \text { word to describe. }\end{array}$ \\
\hline 3 & $\begin{array}{l}\text { Treatment 2: } \\
\text { Descriptive text }\end{array}$ & $\begin{array}{l}\text { They did the same as with previous } \\
\text { meeting discuss about buildings but the } \\
\text { student arrangement } 1 \text { sentences to } \\
\text { describe it. }\end{array}$ \\
\hline 4 & Post test : & $\begin{array}{l}\text { In this meeting, the researcher } \\
\text { conducted a post-test with the gave } \\
\text { them } 1 \text { picture as a snowball to describe } \\
\text {, but the snowball more complicated } \\
\text { than the first meeting. }\end{array}$ \\
\hline
\end{tabular}

The last session for cycle I reflects. In this step, the researcher made some implications from the observations that founding for in time of the learning-teaching process. It starts from pretest. The students admitted that the test aid was surprising because they have lack of vocabulary and a lack of insight into the topics the researchers gave them. However, their willingness to test is still there. The test is done well although there are some students who doing badly. The average pre-test score is only 60.42 .

This score is very low, while the score minimum of this test to pass is 60.00 . In addition, low ability in students is because they just have minimum vocabulary mastering so that it is difficult to decrypt theopic. Most students has know about the topics they will explain, but almost some students have a minimal vocabulary.During the treatment, 1 and 2, the researcher trying to observe for understanding what are students need from the way the students describe a topic each group represents its group using the snowball throwing technique.

In the first treatment, the students looked confused. They are not sure what to do. They still need teacher guidance to do just about everything in every step. The students still feel uncomfortable when describing using the technique as they are in the lead to deepen his knowledge regarding their vocabulary.They are still hesitant when expressing their ideas, and it becomes a barrier to classroom action research.

However, after finishing treatment 2, researchers noticed that work enjoyment began to emerge. They began to dare to express the idea in describing a topic that the researchers gave. This was accompanied by an improvement in post-test score reaching 79.00. From this treatment in cycle 1 , we can draw the conclusion that there are negative and positive results found during the teaching and learning process. 
The positive result is that students begin showing the vocabulary development by believing speaking when describing, and the negative result is the noise and disturbance of those discussing the material. Revisions should be made to increase a quality of their learning as good as their average value. Therefore, cycle II is done to continue the research.

\section{Cycle II.}

This cycle covers only four steps as stated in cycle I. In the planning sessions, a change is made of some revisions to the lesson plan. In the previous treatment, noise and disturbance still happened during the learning and teaching process. For revisions, researchers create different partners for each student. Then, he makes the students describe the topic with the same technique. They are prepared with pieces of drawings and worksheets and because of that step they will be more interested in talking. This strategy is supposed to reduce noise and disturbance. The acting session includes three meetings, since the pre-test used for this cycle is taken from the post-test of the previous cycle as seen in $2^{\text {nd }}$ table below:

Table 2.Meetings in cycle II

\begin{tabular}{cll}
\hline Meeting & Topic & Observing \\
\hline 5 & $\begin{array}{l}\text { Treatment 3 : } \\
\text { Descriptive text }\end{array}$ & $\begin{array}{l}\text { They discuss about the descriptive text } \\
\text { and write down some vocabulary that } \\
\text { they want to say . The researchers give } \\
\text { theme school building to discuss and } \\
\text { students gave 1 sentences to describe. }\end{array}$ \\
\hline 6 & Treatment 4: & $\begin{array}{l}\text { They did the same as with previous } \\
\text { meeting discuss about school building } \\
\text { but the student arrangement 7 sentences } \\
\text { to describe it. }\end{array}$ \\
\hline 7 & Post test: & $\begin{array}{l}\text { In this meeting, the researcher conducted } \\
\text { a post-test with the gave them 1 picture } \\
\text { about school building to describe , but } \\
\text { students must describe it more detail }\end{array}$ \\
\hline
\end{tabular}

Reflecting of the observation done would be discussed in this section. There were much improvement in every meeting. The improvement were as attend: (1) their score on post-test 2 was increased. From 62.02 for pre-test, it was improved to be 80.00 and for the post-test 2 , their score improved until $83.33 \%$.

\section{Discussion}

This research begins with the aim of improving the ability in speaking ability by Snowball Throwing Game technique. Through two cycles, two test and five treatments, the process of teaching and learning were carried out and run so well on the class XI students of Vocational high school level. As it is shown on the data above that the enhancement of score has reached the target which is 8.0, the research will not be continued to third cycle. The use of this method true can upgrade the ability of students speaking to their vocabulary quantitatively, through the enchancement of score, and qualitatively, through the enchancement of behavior and attitude. As stated before, Snowball throwing game can help students increase vocabulary and improving their vocabulary of a topic because they discuss it with their friend in group. With this game, students can express anything they want to tink and it can makes them feel free to describe 
something by topic.

\section{CONCLUSION}

The conclusions are drawn based on the implementation and data analysis. First, there was a significant increase in speaking performance between the eleventh graders of SMK BBU Padalarang before and after taught through by using games.

Second, the students that learning using games got higher score in the posttest, it shows that snowball throwing games can improve speaking ability and increase students vocabulary. Researcher suggesting the english teacher to apply this game in the class for the better technique of teaching.

games can be applied by teacher of English in teaching speaking or writting. It can enhance students' speaking or writting performance. For the teachers of English who want to use games in their classroom, they should consider the time allocation in applying. In addition, the teachers should be patient in explaining and applying Games because the situation and condition of students sometimes are unpredictable. Students also need more time for learning and practicing English speaking. The teachers should also notice that every student gets the same opportunity to practice English speaking and make the situation be more active.

\section{ACKNOWLEDGMENTS}

We would like to thank the principal, teachers and all of the members of the students from the Eleventh grade Vocational High School of Budi Bakti Utama Padalarang, for their gracious help in admitting our research. We would also like to thanks to Mrs Evie Kareviati, M.Pd, one of the lecturer of English Education Department at IKIP Siliwangi who has given his suggestions and critics.

\section{REFERENCES}

Agus, S. (2009). Cooperative Learning : Teori Dan Aplikasi Paikel. In Cooperative Learning: Teori Dan Aplikasi Paikem. Yogyakarta: Gramedia.

Apsari, Y. (2018). Snowball Throwing in Teaching Grammar. Lingual, 10(1), 52-59.

Jack Richard. (2006). Communicative Language Teaching Today (Passages, Ed.). New York:

Cambridge University Press.

Kemendikbud. (2013). The Implementation Of Indonesia Curriculum.

Parmawati, A. (2018). Using Analytic Teams Technique To Improve Students'speaking Skill. Edulitics (Education, Literature, And Linguistics) Journal, 3(2), 21-25.

Parmawati, A., \& Inayah, R. (2019). Improving Students'speaking Skill Through English Movie In Scope Of Speaking For General Communication. Eltin Journal, Journal Of English Language Teaching In Indonesia, 7(2), 43-53.

Puspita Ensa. (2018). The Use Of Games In Teaching English. Skripsi, 1, 4.

Stapa, S. H. (2008). Snowball Throwing Games. Jakarta: Gramedia.

Tengku Mohamad Maasum, T. N. R., Mustaffa, R., \& Stapa, S. H. (2016). Young Learners' Perceptions Of Learning English Using Language Games In A Non - Formal Context. Mediterranean Journal Of Social Sciences, (December). Https://Doi.Org/10.5901/Mjss.2015.V6n6s5p375

Wright. (2005). No Title. Games As Provide Communication. 